\title{
Cr(III) oxidation coupled with Mn(II) bacterial oxidation in the environment
}

\author{
Ji-Zheng He • You-Ting Meng • Yuan-Ming Zheng • \\ Li-Mei Zhang
}

Received: 18 June 2009 / Accepted: 2 September 2009/Published online: 17 September 2009

(C) Springer-Verlag 2009

\begin{abstract}
Purpose Cr(III) oxidation to $\mathrm{Cr}(\mathrm{VI})$ significantly increases $\mathrm{Cr}$ mobility and toxicity and thus its environmental risks. Manganese (Mn) oxides may serve as the potential oxidants of $\mathrm{Cr}(\mathrm{III})$ in environment. Natural $\mathrm{Mn}$ oxides in the environment are believed to be derived from bacterial oxidation. The objective of this study was to examine the $\mathrm{Cr}(\mathrm{III})$ oxidation capacity of biogenic $\mathrm{Mn}$ oxide and the role of Mn-oxidizing bacteria in $\mathrm{Cr}$ (III) oxidation.

Materials and methods Batch experiments were conducted to investigate the capacities of $\mathrm{Cr}(\mathrm{III})$ oxidation by chemically synthetic Mn oxides and biogenic Mn oxide. Biogenic Mn oxide was formed by Bacillus sp. WH4, a $\mathrm{Mn}$-oxidizing bacterium isolated from $\mathrm{Fe}-\mathrm{Mn}$ nodules of a Chinese soil. Various $\mathrm{Cr}(\mathrm{III})$ and $\mathrm{Mn}$ (II) were added to the growth medium of Bacillus sp. WH4 to evaluate $\mathrm{Cr}$ (III) oxidation coupled with $\mathrm{Mn}$ (II) bacterial oxidation.

Results The Cr(III) oxidation capacity of biogenic Mn oxide was $0.24 \mathrm{mmol} \mathrm{g}^{-1}$ and higher than three chemically synthetic Mn oxides. No Mn(III) intermediate was detected during Mn (II) bacterial oxidation. Bacillus sp. WH4 could promote $\mathrm{Cr}$ (III) oxidation through oxidizing Mn(II), although it could not oxidize Cr(III) directly.

Conclusions The participation of Mn-oxidizing bacteria makes $\mathrm{Cr}(\mathrm{III})$ oxidation more complicated in environment.
\end{abstract}

Responsible editor: Hailong Wang

J.-Z. He $(\bowtie) \cdot$ Y.-T. Meng · Y.-M. Zheng • L.-M. Zhang

State Key Laboratory of Urban and Regional Ecology,

Research Center for Eco-Environmental Sciences,

Chinese Academy of Sciences,

Shuangqing Road18,

Beijing 100085, China

e-mail: jzhe@rcees.ac.cn

Y.-T. Meng

Graduate School, Chinese Academy of Sciences,

Beijing 100039, China
These findings illustrate the need to consider bacterial activity and the $\mathrm{Mn}(\mathrm{II})$ level when predicting the fate of $\mathrm{Cr}$ and the potential applications of $\mathrm{Mn}$ oxides in the remediation of pollutants in environment.

Keywords Biogenic Mn oxide · Chromium · Mn(III) intermediate $\cdot$ Mn-oxidizing bacteria $\cdot$ Oxidation

\section{Introduction}

Hexavalent chromium $(\mathrm{Cr})$ is a toxic heavy metal and often considered to be originating from industrial activity (Bartlett and James 1988). However, natural high Cr(VI) concentration in aqueous solution (up to $73 \mu \mathrm{g} \mathrm{l}^{-1}$ ) was observed in many sites far away from the industrial areas (Oze et al. 2007), suggesting natural $\mathrm{Cr}$ (III) oxidation and transport in the environment. The conversion of $\mathrm{Cr}(\mathrm{III})$ oxidation to $\mathrm{Cr}(\mathrm{VI})$ increases its mobility and toxicity in the environment. Mn oxides, which are common in various environments, are the only known natural oxidants of $\mathrm{Cr}$ (III) (Fendorf and Zasoski 1992; Silvester et al. 1995; Nico and Zasoski 2000) and therefore could control the fate and transport of $\mathrm{Cr}$ in the environment.

Natural Mn oxides in the environment are believed to be derived either directly from biogenic $\mathrm{Mn}$ (II) oxidation or from the subsequent alteration of biogenic Mn oxides ((Kim et al. 2003); (Tebo et al. 2004)). Mn oxidation in natural aquatic systems often proceeds at very slow rate if there is no participation of microorganisms (Nealson et al. 1988). Mnoxidizing microorganisms can accelerate the Mn oxidization rate by up to $10^{5}$ times compared to the abiotic Mn oxidation (Hastings and Emerson 1986). Mn-oxidizing bacteria are a diverse group and have been found in various environments such as soils ((He et al. 2008); (Zhang et al. 2008)), fresh water ((Nelson et al. 1999); (Villalobos et al. 2003)), and 
oceans (Rosson and Nealson 1982). Molecular genetic approaches have revealed that all Mn-oxidizing organisms share sequence similarity with multicopper oxidase enzymes (Tebo et al. 2004). Biogenic Mn oxides are often poorly crystalline nano-sized particulates with many structural defects (Bargar et al. 2005). Such biogenic Mn oxides are expected to be reactive with heavy metals effectively through adsorption ((Nelson et al. 1999); (Villalobos et al. 2005); (Toner et al. 2006); (Meng et al. 2009); (Jin et al. 2009)) and oxidation (Lee and Tebo 1994; (Murray and Tebo 2007); (Murray et al. 2007); (Chinni et al. 2008); (Ohnuki et al. 2008)).

$\mathrm{Cr}$ (III) oxidation by various $\mathrm{Mn}$ oxides has been studied with abiotic Mn oxides ((Chung et al. 1994); (Silvester et al. 1995); (Nico and Zasoski 2000)). Despite considerable studies, the mechanism by which $\mathrm{Mn}$ oxides transform $\mathrm{Cr}$ (III) to $\mathrm{Cr}(\mathrm{VI})$ is not fully understood. $\mathrm{Mn}(\mathrm{III})$ is considered to be typically the initial product of the abiotic oxygenation of aqueous Mn(II) (Morgan 2005) or formed from Mn(II) bacterial oxidation (Webb et al. 2005). As a specific structural and compositional feature, $\mathrm{Mn}$ (III) plays an important and previously unrecognized role in the fate and transport of many multivalent compounds ((Murray and Tebo 2007); (Murray et al. 2007); (Nico and Zasoski 2000)). Although there are some empirical and theoretical evidence that Mn(III) be related to Cr(III) oxidation (Chung et al. 1994), some other researches obtained contrasting results ((Silvester et al. 1995); (Weaver and Hochella 2003); (Murray and Tebo 2007)).

The purpose of this study was to evaluate $\mathrm{Cr}$ (III) oxidation capacity of the biogenic Mn oxide compared with chemically synthetic Mn oxides and the $\mathrm{Cr}$ (III) oxidation process in the presence of Mn-oxidizing bacteria and $\mathrm{Mn}(\mathrm{II})$. Bacillus sp. WH4, a Mn-oxidizing bacterium isolated from $\mathrm{Fe}-\mathrm{Mn}$ nodules of a Chinese soil, was suitable for this study because the mature spores can oxidize Mn(II) but the vegetative cells cannot, thus excluding bacterial cell growth as an experimental variable (Zhang et al. 2008). To detect whether Mn (III) intermediate was formed and played a role in $\mathrm{Cr}$ (III) oxidation, pyrophosphate and EDTA were chosen as trapping ligands of $\mathrm{Mn}$ (III) in $\mathrm{Mn}(\mathrm{II})$ bacterial oxidation (Klewicki and Morgan 1998).

\section{Materials and methods}

\subsection{Chemicals}

Deionized water and analytical grade or better chemicals were used to prepare all aqueous solutions. $\mathrm{Cr}$ (III) and $\mathrm{Mn}$ (II) stock solutions were prepared with $\mathrm{CrCl}_{3}$ and $\mathrm{MnCl}_{2}$. $\mathrm{Mn}$ (III) trapping ligands were sodium pyrophosphate $\left(\mathrm{Na}_{4} \mathrm{P}_{2} \mathrm{O}_{7} 10 \mathrm{H}_{2} \mathrm{O}\right.$; Sinopharm Chemical Reagent Co. Ltd, China) and ethylenediaminetetraacetate $\left(\mathrm{C}_{10} \mathrm{H}_{14} \mathrm{~N}_{2} \mathrm{Na}_{2} \mathrm{O}_{8}\right.$ $2 \mathrm{H}_{2} \mathrm{O}$, EDTA; Amersco Inc, USA).

\subsection{Mn oxide preparation}

\subsubsection{Chemically synthetic Mn oxides}

Three chemically synthetic Mn oxides were used. Todorokite was synthesized by refluxing process at atmospheric pressure (Feng et al. 2004b). Birnessite was synthesized by mixing $\mathrm{MnCl}_{2}$ and $\mathrm{NaOH}$ (Feng et al. 2004a). Cryptomelane was synthesized by heating $\mathrm{MnSO}_{4}$ and $\mathrm{KMnO}_{4}$ solution (Feng et al. 2007).

\subsubsection{Biogenic Mn oxide}

Bacillus sp. WH4 was isolated from the $\mathrm{Fe}-\mathrm{Mn}$ nodules of a Chinese soil (Zhang et al. 2008). By XRD and TEM analyses, the biogenic Mn oxides formed by Bacillus sp. WH4 was of poor crystallinity and nano-sized particulates (Meng et al. 2009). In this study, Bacillus sp. WH4 was grown in modified $\mathrm{K}$ medium (Meng et al. 2009) at $27 \pm 1^{\circ} \mathrm{C}$ with $1.0 \mathrm{mM} \mathrm{MnCl}_{2}$. Prior to the addition of sterilized $N-2$ hydroxyethylpiperazine- $N$ '-2-ethanesulfonic acid (HEPES, Amresco Inc, USA) and $\mathrm{MnCl}_{2}(0.22-\mu \mathrm{m}$ filters, $\mathrm{pH} 7.5)$, the medium was autoclaved for $30 \mathrm{~min}$ at $115^{\circ} \mathrm{C}$. After 14 days, the fresh biogenic Mn oxide was harvested and cleaned with deionized water three times. The preformed biogenic Mn oxide was prepared to evaluate its $\mathrm{Cr}(\mathrm{III})$ oxidation capacity. The fresh and performed biogenic $\mathrm{Mn}$ oxide concentration was measured by LeducoBerbelin Blue (LBB) assay (Krumbein and Altmann 1973).

\subsection{Experimental setup}

\subsubsection{Direct oxidation of Cr(III) by Mn oxides}

$\mathrm{Cr}$ (III) oxidation by the chemically synthetic Mn oxides and the performed biogenic $\mathrm{Mn}$ oxide were evaluated on a reciprocating shaker at $150 \mathrm{rpm}$ and $25 \pm 1^{\circ} \mathrm{C}$. The oxidation tests were performed in $100-\mathrm{ml}$ centrifugal tubes containing $10 \mathrm{ml}$ mixed suspension at $\mathrm{pH}$ 5.0. The standard suspension for all experiments contained $10.0 \mathrm{mM} \mathrm{NaCl}, 2.0 \mathrm{~g} \mathrm{l}^{-1} \mathrm{Mn}$ oxides, and $0.5 \mathrm{mM} \mathrm{Cr}$ (III) (as $\mathrm{CrCl}_{3}$ ). The blank control contained $0.5 \mathrm{mM} \mathrm{Cr}$ (III) in $10.0 \mathrm{mM} \mathrm{NaCl}$. All reactions were carried out with three replicates.

At the end of each experiment, $\mathrm{Cr}(\mathrm{VI})$ concentration was obtained from the supernatant by centrifugation $(11,000 \mathrm{rpm}$, $10 \mathrm{~min}$ ).

\subsubsection{Cr(III) oxidation by the fresh biogenic Mn oxide}

To detect whether Bacillus sp. WH4 could oxidize Cr(III) directly, $0-100 \mu \mathrm{M} \mathrm{Cr}\left(\mathrm{III}\right.$ ) (as $\mathrm{CrCl}_{3}$ ) was directly inoculated into the growth medium (section 2.2.2) with Bacillus sp. WH4 (no Mn(II) added). The concentration of 
$\mathrm{Cr}(\mathrm{VI})$ in the medium and the growth curve (OD600) of Bacillus sp. WH4 were measured.

To determine whether $\mathrm{Mn}(\mathrm{III})$ intermediate was formed during $\mathrm{Mn}$ (II) bacterial oxidation, $0.1-1.0 \mathrm{mM} \mathrm{Mn(II)} \mathrm{(as}$ $\mathrm{MnCl}_{2}$ ) and $0.4 \mathrm{mM}$ pyrophosphate or EDTA were added into the growth medium with Bacillus sp. WH4. Mn(III) content was measured after filtration through $0.22-\mu \mathrm{m}$ filter ((Klewicki and Morgan 1998); (Webb et al. 2005)). In the blank control (only $\mathrm{Mn}$ (II) and Bacillus sp. WH4), LBB assay (see Section 2.4) was also used to test the production of $\mathrm{Mn}(\mathrm{III})$ in the supernatant (centrifugation at 11,000 rpm, $10 \mathrm{~min}$ ). If $\mathrm{Mn}(\mathrm{III})$ was formed and existed in the aqueous solution, it could be reduced by LBB.

To test $\mathrm{Cr}$ (III) oxidation coupled with $\mathrm{Mn}$ (II) bacterial oxidation, $0-100 \mu \mathrm{M} \mathrm{Cr}$ (III) and/or Mn(II) was added to the growth medium in the presence of Bacillus sp. WH4. Firstly, the $100-\mathrm{ml}$ flasks with $30 \mathrm{ml}$ medium were incubated with Bacillus sp. WH4 for 3 days (after 3 days, the spores reached about $90 \%$ in the medium). The sterilized $\mathrm{Mn}$ (II) and/or $\mathrm{Cr}$ (III) $(0.22-\mu \mathrm{m}$ filter) were added into the medium. After another 5 days, aliquots of the incubations were removed with a syringe to analyze fresh biogenic Mn oxide concentrations. For $\mathrm{Cr}(\mathrm{VI})$ analysis, cells and $\mathrm{Mn}$ oxides were removed by filtration $(0.22-\mu \mathrm{m}$ filters), which could also quench the $\mathrm{Cr}(\mathrm{III})$ oxidation reaction. $\mathrm{Cr}(\mathrm{VI})$ concentration in the pure growth medium (without $\mathrm{Mn}(\mathrm{II})$ ) and Bacillus sp. WH4 was also determined.

\subsection{Measurements}

The reductive dye LBB (Sigma-Aldrich, USA) was used to determine the Mn oxide concentration (OD620; (Krumbein and Altmann 1973)). Oxidized LBB is blue in color, and the degree of coloration is a function to quantify the amount of $\mathrm{Mn}$ oxides (assuming all oxidized $\mathrm{Mn}$ exist as $\mathrm{MnO}_{2}$ ). No color reaction between $\mathrm{LBB}$ and $\mathrm{Cr}(\mathrm{III})$ (or $\mathrm{Cr}(\mathrm{VI})$ ) was observed. LBB assay was also used to detect possible Mn (III) during $\mathrm{Mn}(\mathrm{II})$ bacterial oxidation. $\mathrm{Cr}(\mathrm{VI})$ was analyzed by colorimetric diphenylcarbazide assay at $540 \mathrm{~nm}$ (Urone 1955), and its detect limit is $4 \mu \mathrm{g} \mathrm{l}{ }^{-1}$ with $50 \mathrm{ml}$ colorimetric tube. All colorimetric measurements were made on a Spectra Max190 reader (MD Co. Ltd.).

\subsection{Data analysis}

The efficiency of biogenic Mn oxide was defined as follows:

Efficiency of biogenic Mn oxide $=[\mathrm{Cr}(\mathrm{VI})] /[$ biogenic Mn oxide $]$

where $[\mathrm{Cr}(\mathrm{VI})]$ is the $\mathrm{Cr}(\mathrm{VI})$ concentration oxidized in the medium, mM; [biogenic Mn oxide] is the biogenic Mn oxide concentration in the medium, mM.
All mathematical and graphical operations were made using the software Sigmaplot 10.0 (Systat Software Inc., USA), and the error bars in the plots indicated the standard deviation of three replicates.

\section{Results}

3.1 $\mathrm{Cr}$ (III) oxidation by biotic and abiotic Mn oxides

As shown in Fig. 1, Cr(III) oxidation by the preformed biogenic Mn oxide was higher than those of three chemically synthetic $\mathrm{Mn}$ oxides. The $\mathrm{Cr}(\mathrm{III})$ oxidation capacity of four $\mathrm{Mn}$ oxides were $0.02,0.08,0.15$, and $0.24 \mathrm{mmol} \mathrm{g}^{-1}$ for cryptomelane, todorokite, birnessite, and biogenic Mn oxide, respectively.

\section{2 $\mathrm{Cr}$ (III) oxidation by the fresh biogenic Mn oxide}

\subsubsection{No Mn(III) formation during Mn(II) oxidation by Bacillus sp. WH4}

As shown in Fig. 2, the absorbance peaks of $\mathrm{Mn}$ (III)pyrophosphate and Mn(III)-EDTA complexes in birnessite suspension appeared at 480 and $450 \mathrm{~nm}$, respectively, suggesting that $\mathrm{Mn}(\mathrm{III})$ was trapped by pyrophosphate and EDTA (Klewicki and Morgan 1998; (Webb et al. 2005)).

By adding $0.4 \mathrm{mM}$ sterilized pyrophosphate or EDTA, no absorbance peak at $480 \mathrm{~nm}$ (Mn(III)pyrophosphate) or $450 \mathrm{~nm}$ (Mn(III)-EDTA) was detected during $\mathrm{Mn}(\mathrm{II})$ bacterial oxidation by Bacillus sp. WH4. No color reaction between supernatant and LBB

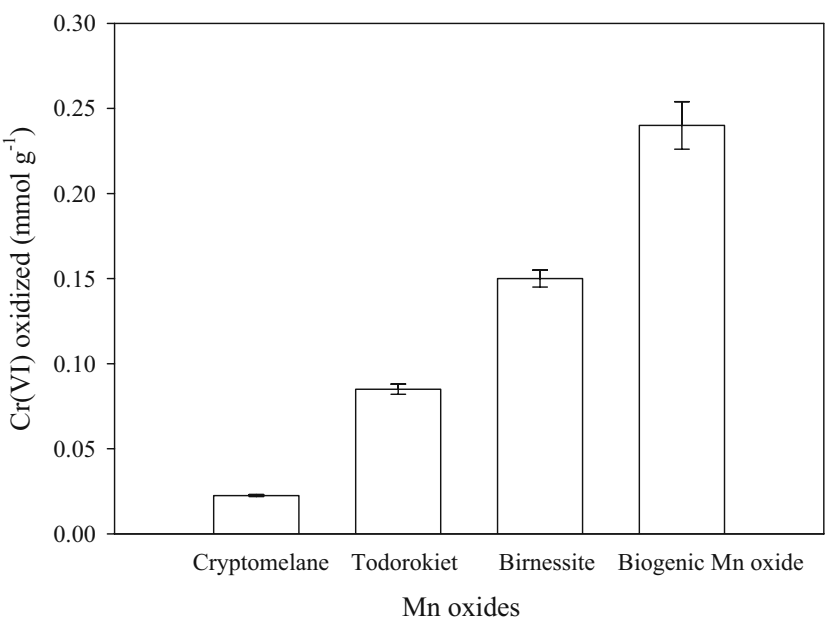

Fig. $1 \mathrm{Cr}(\mathrm{III})$ oxidation by chemically synthetic and performed biogenic $\mathrm{Mn}$ oxides at $\mathrm{pH} 5.0$. [Mn oxides] $=2.0 \mathrm{~g} \mathrm{l}^{-1},[\mathrm{Cr}(\mathrm{III})]=$ $0.5 \mathrm{mM},[\mathrm{NaCl}]=10.0 \mathrm{mM}$. All experiments were conducted for $4 \mathrm{~h}$. The error bars in plots indicated the standard deviation of three replicates 


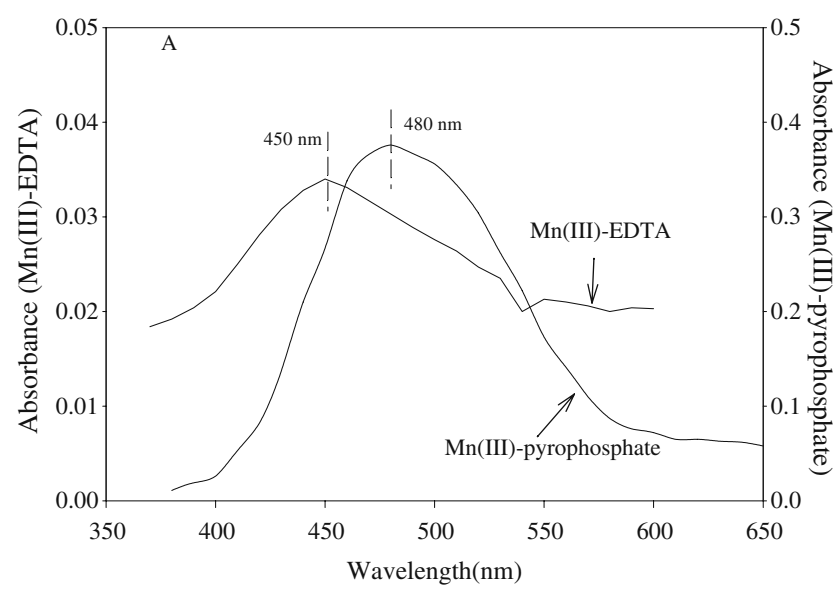

Fig. 2 The absorbance peaks of Mn(III)-pyrophosphate and MnEDTA in birnessite suspension at $\mathrm{pH}$ 5.0. [Pyrophosphate] or $[$ EDTA $]=0.4 \mathrm{mM}$, [birnessite $]=2.0 \mathrm{~g} \mathrm{l}^{-1},[\mathrm{NaCl}]=10 \mathrm{mM}$

was detected. These results indicated that no $\mathrm{Mn}(\mathrm{III})$ intermediate was formed when $\mathrm{Mn}$ (II) was oxidized by Bacillus sp. WH4.

\subsubsection{No Cr(III) oxidation directly by Bacillus sp. WH4}

With $0-100 \mu \mathrm{M} \operatorname{Cr}(\mathrm{III})$ in the growth medium of Bacillus sp. WH4, no Cr(VI) was detected, implying that Bacillus sp. WH4 could not oxidize Cr(III) directly. The growth curves of Bacillus sp. WH4 were measured, and the microbial growth were not suppressed significantly by the added Cr(III) after $24 \mathrm{~h}$, as shown in Fig. 3. Thus, the inhibitions of $\mathrm{Cr}(\mathrm{III})$ on microbial growth and the direct microbial oxidation of $\mathrm{Cr}(\mathrm{III})$ were excluded.

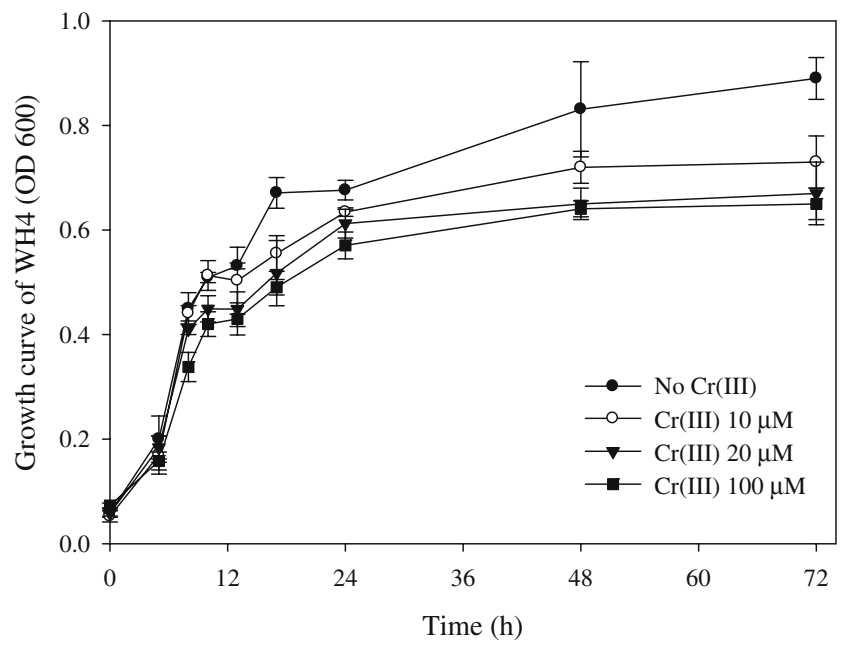

Fig. 3 Growth curves of Bacillus sp. WH4 in culture medium with various $\mathrm{Cr}(\mathrm{III})$ at $\mathrm{pH}$ 7.5. No $\mathrm{Mn}(\mathrm{II})$ was added. The error bars in plots indicated the standard deviation of three replicates

\subsubsection{Cr(III) oxidation under various $\mathrm{Mn}$ (II) and $\mathrm{Cr}$ (III) concentrations}

Biogenic Mn oxide concentration increased with Mn(II) concentration and did not reach a plateau up to $1.0 \mathrm{mM}$ $\mathrm{Mn}(\mathrm{II})$ regardless what levels of $\mathrm{Cr}(\mathrm{III})$ (Fig. 4a). Higher $\mathrm{Cr}$ (III) concentration led higher biogenic Mn oxide production, implying that $\mathrm{Mn}(\mathrm{II})$ oxidation was stimulated by $\mathrm{Cr}(\mathrm{III})$.

The highest $\mathrm{Cr}(\mathrm{VI})$ concentrations in the medium were $1.0 \mu \mathrm{M}$ (equal to $52.0 \mu \mathrm{g}^{-1}$ ) and $1.9 \mu \mathrm{M}$ (equal to $98.9 \mu \mathrm{g} \mathrm{l}^{-1}$ ) for $50 \mu \mathrm{M} \mathrm{Cr}(\mathrm{III})$ and $100 \mu \mathrm{M} \mathrm{Cr}(\mathrm{III})$, respectively. The efficiencies of biogenic $\mathrm{Mn}$ oxide decreased with $\mathrm{Mn}$ (II) concentration and then reached a plateau for two $\mathrm{Cr}(\mathrm{III})$ concentrations. Furthermore, the efficiency of biogenic Mn oxide with $100 \mu \mathrm{M}$ Cr(III) was lower than that with $50 \mu \mathrm{M} \mathrm{Cr}(\mathrm{III})$, indicating that $\mathrm{Cr}(\mathrm{III})$ oxidation was not proportional to biogenic $\mathrm{Mn}$ oxide concentrations.

\section{Discussion}

Cr(III) oxidation was largely affected by its adsorption on the surface of Mn oxides. Biogenic Mn oxides are poorly crystalline nano-size particulates with huge specific surface area and higher binging energy (Tebo et al. 2004). Therefore, $\mathrm{Cr}(\mathrm{III})$ could be easily adsorbed on the surface of biogenic Mn oxide and then be oxidized. The results in this study supported this explanation. It is shown that the $\mathrm{Cr}(\mathrm{III})$ oxidation capacity of biogenic Mn oxide formed by Bacillus sp. WH4 was higher than three

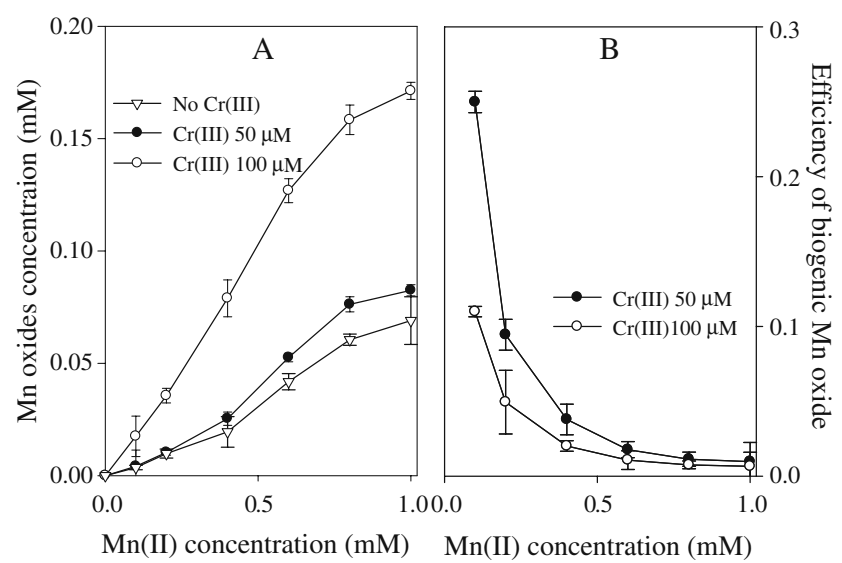

Fig. $4 \mathrm{Mn}(\mathrm{II})$ and $\mathrm{Cr}(\mathrm{III})$ oxidation with various of $\mathrm{Mn}(\mathrm{II})$ and $\mathrm{Cr}$ (III) concentrations in the presence of Bacillus sp. WH4. $\mathrm{pH}=7.5$. $[\mathrm{Mn}(\mathrm{II})]=0-1.0 \mathrm{mM},[\mathrm{Cr}(\mathrm{III})]=0-100 \mu \mathrm{M}$. a Biogenic Mn oxide concentration; $\mathbf{b}$ the efficiency of biogenic Mn oxide. The efficiency of biogenic Mn oxide was the molar ratio of $\mathrm{Cr}(\mathrm{VI})$ to biogenic $\mathrm{Mn}$ oxide. The error bars in plots indicated the standard deviation of three replicates 
Table 1 Summary of $\mathrm{Cr}(\mathrm{III})$ oxidation in relation to $\mathrm{Mn}$ (III) intermediate in literatures

\begin{tabular}{|c|c|c|}
\hline Mn oxides types & Relationship with $\mathrm{Mn}(\mathrm{III})$ & Reference \\
\hline $\mathrm{Mn}(\mathrm{III})$ & $\begin{array}{l}\text { Yes - aqueous } \mathrm{Mn}(\mathrm{III}) \text { showed to oxidize } \\
\mathrm{Cr}(\mathrm{III}) \text { in acidic conditions }\end{array}$ & (Rophael 1982) \\
\hline $\begin{array}{l}\text { Three abiotic Mn oxides: birnessite, } \\
\text { pyrolusite, hausmannite }\end{array}$ & $\begin{array}{l}\text { Yes-Mn oxides containing highest } \mathrm{Mn}(\mathrm{III}) \\
\text { concentration increase the rate of } \mathrm{Cr} \text { oxidation }\end{array}$ & (Chung et al. 1994) \\
\hline Abiotic $\delta-\mathrm{MnO}_{2}$ & $\begin{array}{l}\text { Yes - Cr oxidation rate slowed when pyrophosphate } \\
\text { was used to trap available } \mathrm{Mn}(\mathrm{III})\end{array}$ & (Nico and Zasoski 2000) \\
\hline $\begin{array}{l}\text { Six natural Mn oxides: pyrolusite, hausmannite, } \\
\text { manganite, romanechite, cryptomelate, lithiophorite; } \\
\text { One synthetic birnessite }\end{array}$ & $\begin{array}{l}\text { Yes - } \mathrm{Cr}(\mathrm{III}) \text { oxidation is most related to the } \\
\text { presence of } \mathrm{Mn}(\mathrm{III})\end{array}$ & (Weaver and Hochella 2003) \\
\hline Abiotic $\mathrm{Na}$-buserite & No & (Silvester et al. 1995) \\
\hline $\mathrm{Mn}(\mathrm{III})$ (pH 3, aqueous) & No & (Weaver et al. 2002) \\
\hline $\begin{array}{l}\text { Five } \mathrm{Mn}(\mathrm{III}) \text { complex: } \mathrm{Mn}(\mathrm{III})-\mathrm{PVD}, \mathrm{Mn}(\mathrm{III})-\mathrm{DFO} \text {, } \\
\mathrm{Mn}(\mathrm{III}) \text {-pyrophosphate, } \mathrm{Mn}(\mathrm{III})-\text { citrate, } \mathrm{Mn} \text { (III)-Bis Tris }\end{array}$ & No & (Murray and Tebo 2007) \\
\hline A biogenic Mn oxide formed by Bacillus sp. WH4 & No & This study \\
\hline
\end{tabular}

chemically synthetic Mn oxides. Recent studies also reported that biogenic $\mathrm{Mn}$ oxide produced by Bacillus sp. SG-1 had a higher reactivity than synthetic Mn oxides and oxidized $\mathrm{Cr}(\mathrm{III})$ seven times faster than $\delta-\mathrm{MnO}_{2}$ (Murray and Tebo 2007).

Since $\mathrm{Cr}(\mathrm{III})$ oxidation capacity of preformed biogenic Mn oxide was higher than synthetic Mn oxides, how about the $\mathrm{Cr}$ (III) oxidation in real environment? Do Mnoxidizing bacteria play a role in $\mathrm{Cr}$ (III) oxidation? Therefore, various concentrations of $\mathrm{Cr}$ (III) and $\mathrm{Mn}$ (II) were added to Bacillus sp. WH4 to detect the possible reactions. In the presence of Mn-oxidizing bacteria, $\mathrm{Cr}$ (III) could be oxidized by Mn oxides via several approaches (Murray and Tebo 2007): (1) the direct Cr(III) oxidation by Mn-oxidizing bacteria, (2) Mn(III) intermediate formation during bacterial oxidation to oxidize $\mathrm{Cr}$ (III), or (3) rapid biogenic Mn oxide formation to oxidize $\mathrm{Cr}(\mathrm{III})$. Therefore, there are three key questions to answer.

The first one was about the $\mathrm{Cr}$ (III) oxidation by Mnoxidizing bacteria. Since Bacillus sp. WH4 was tolerant to $\mathrm{Mn}$ (II) and could oxidize Mn(II) efficiently (up to $10 \mathrm{mM}$; (Meng et al. 2009)), could it oxidize Cr(III) directly? In this study, $\mathrm{Cr}$ (III) could not be oxidized by Bacillus sp. WH4 and neither significant toxic effect of $\mathrm{Cr}$ (III) on this bacterium was found. It was the same with the results of Bacillus sp. SG-1 and Pseudomonas putida strain GB-1, which could not oxidize Cr(III) directly ((Murray et al. 2007); (Murray et al. 2005)).

The second question was that whether Mn(III) intermediate was formed during the Mn(II) bacterial oxidation. Mn (III) intermediate in Mn oxides was assumed to play a role in the $\mathrm{Cr}$ (III) oxidation according to the electron-transfer theory (Nico and Zasoski 2000). The theory suggested that an innersphere complex formation between $\mathrm{Cr}$ (III) and $\mathrm{Mn}$ (IV) could easily be rate limiting since both $\mathrm{Mn}(\mathrm{IV})$ and $\mathrm{Cr}$ (III) are $\mathrm{d}^{3}$ ions with very slow ligand exchange rates.
Conversely, $\mathrm{Mn}(\mathrm{III})$ is a high spin $\mathrm{d}^{4}$ ions with much faster ligand exchange kinetics (Klewicki and Morgan 1998). Therefore, the innersphere complex formation of $\mathrm{Cr}$ (III) with $\mathrm{Mn}$ (III) is likely to be quicker than with $\mathrm{Mn}(\mathrm{IV})$. Furthermore, one Mn(III) and one Mn(IV) could oxidize one $\mathrm{Cr}$ (III) as following reaction equation (Nico and Zasoski 2000):

$\mathrm{Mn}(\mathrm{III})+\mathrm{Mn}(\mathrm{IV})+\mathrm{Cr}(\mathrm{III}) \rightarrow \mathrm{Cr}(\mathrm{VI})+2 \mathrm{Mn}(\mathrm{II})$

Although $\mathrm{Mn}(\mathrm{III})$ seemed to be important in $\mathrm{Cr}(\mathrm{III})$ oxidation, no Mn(III) intermediate was detected during Mn (II) bacterial oxidation in this study. This is consistent with the result of Bacillus sp. SG-1 where no relationship of Mn

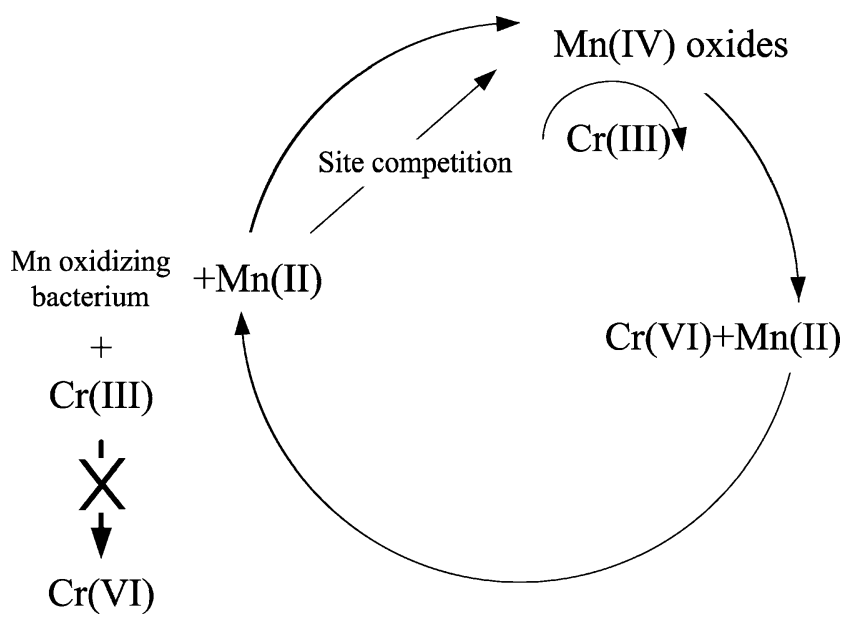

Fig. 5 Schematic pathway of $\mathrm{Cr}$ oxidation coupled with $\mathrm{Mn}$ (II) bacterial oxidation. Biogenic $\mathrm{Mn}$ oxide formed by Mn-oxidizing bacterium could oxidize $\mathrm{Cr}(\mathrm{III})$ to $\mathrm{Cr}(\mathrm{VI})$. The reductive $\mathrm{Mn}(\mathrm{II})$ was re-supplied to the Mn-oxidizing bacterium. Then a cycle was created: Mn-oxidizing bacteria promote $\mathrm{Cr}$ (III) oxidation through oxidizing $\mathrm{Mn}(\mathrm{II})$, and $\mathrm{Mn}$ was recycled. Higher $\mathrm{Mn}(\mathrm{II})$ would inhibit $\mathrm{Cr}(\mathrm{III})$ oxidation through physical blocking or site competition 
(III) and $\mathrm{Cr}(\mathrm{III})$ oxidation was found (Murray and Tebo 2007) and the result of $P$. putida MnB1, which showed that $\mathrm{Cr}(\mathrm{III})$ oxidation was only dependent upon the biogenic $\mathrm{Mn}$ (IV) oxides formation (Wu et al. 2005). Although Mn(III) in aqueous solution was shown to oxidize $\mathrm{Cr}$ (III) (Rophael 1982), the acidic condition was not comparable to those found in natural $\mathrm{pH}$ in this study (Table 1).

The third question was whether reactive biogenic Mn oxide was formed and the answer was yes. It is proposed that the process of $\mathrm{Cr}(\mathrm{III})$ oxidation be described as: (1) biogenic Mn oxide formation by Bacillus sp. WH4 and (2) $\mathrm{Cr}(\mathrm{III})$ adsorption and reaction on the surface of the biogenic Mn oxide. Although $\mathrm{Cr}$ (III) could not be oxidized directly by the bacterium, it could bind to the oxidizing sites of the bacterium and compete for the sites with $\mathrm{Mn}$ (II) at the same time. If this were true, high levels of $\mathrm{Mn}(\mathrm{II})$ could alleviate the inhibition of both $\mathrm{Mn}$ (II) and $\mathrm{Cr}$ (III) oxidation caused by $\mathrm{Cr}(\mathrm{III})$ competition. Although $\mathrm{Mn}$ oxide concentration increased with increasing $\mathrm{Mn}(\mathrm{II})$, high level $\mathrm{Cr}$ (III) in the system promoted $\mathrm{Mn}$ (II) oxidation by Bacillus sp. WH4 (see Fig. 4a). This is different from the result of Bacillus sp. SG-1, which showed that neither $\mathrm{Cr}$ (III) nor $\mathrm{Cr}(\mathrm{VI})$ influenced $\mathrm{Mn}(\mathrm{II})$ oxidation (Murray and Tebo 2007). Furthermore, higher Mn(II) concentration led to decreasing efficiencies of biogenic Mn oxide for two $\mathrm{Cr}$ (III) concentrations (Fig. 4b), which is similar to the recent result of Bacillus sp. SG-1 where higher Mn(II) concentration inhibited $\mathrm{Cr}$ (III) oxidation (Murray and Tebo 2007). For two concentrations of $\mathrm{Cr}(\mathrm{III})$, the efficiency of biogenic $\mathrm{Mn}$ oxide with lower Mn oxide concentration was higher than the higher one, and it is similar with the result of $P$. putida $\mathrm{MnB1}$ where $\mathrm{Cr}(\mathrm{III})$ oxidation rate was not directly proportional to the amount of $\mathrm{Mn}$ oxides (Wu et al. 2005). There are two possible reasons to explain these results.

One is alluded to the surplus Mn (II) inhibition. With a little $\mathrm{Mn}(\mathrm{II})$, the formed fresh Mn oxides started to adsorb and oxidize $\mathrm{Cr}(\mathrm{III})$, after then, $\mathrm{Mn}$ (II) was regenerated to be oxidized by Bacillus sp. WH4. It means that a cycle of Mn (II) and $\mathrm{Cr}$ (III) oxidation could be created, and $\mathrm{Mn}$ is recycled. The Mn-oxidizing bacterium could promote $\mathrm{Cr}$ (III) oxidation through forming reactive biogenic Mn oxide, as presented in Fig. 5. Additionally, Mn(II) could also be adsorbed on biogenic Mn oxide and be oxidized. Higher concentration of $\mathrm{Mn}$ (II) would compete with $\mathrm{Cr}$ (III) for the site on the biogenic $\mathrm{Mn}$ oxide and thus inhibit $\mathrm{Cr}$ (III) oxidation. Another reason is the rate limit. The $\mathrm{Cr}$ (III) oxidation by Mn oxides can be expressed by the following reaction (Fendorf and Zasoski 1992):

$\mathrm{Cr}(\mathrm{III})+1.5 \mathrm{MnO}_{2}+\mathrm{H}_{2} \mathrm{O}=\mathrm{HCrO}_{4}^{-}+1.5 \mathrm{Mn}(\mathrm{II})+\mathrm{H}^{+}$

In this reaction, $\mathrm{Cr}(\mathrm{III})$ must lose three electrons in order to become $\mathrm{Cr}(\mathrm{VI})$. The standard voltages $\left(E^{0}\right)$ for the oxidation of $\mathrm{Cr}(\mathrm{III})$ to $\mathrm{Cr}(\mathrm{IV}), \mathrm{Cr}(\mathrm{IV})$ to $\mathrm{Cr}(\mathrm{V})$, and $\mathrm{Cr}(\mathrm{V})$ to $\mathrm{Cr}(\mathrm{VI})$ are $-2.10,-1.34$, and $-0.55 \mathrm{~V}$, respectively. Thus the removal of the first electron from $\mathrm{Cr}$ (III) should be the slowest electron-transfer step (Nico and Zasoski 2000). In this system, no $\mathrm{Mn}$ (III) was involved in $\mathrm{Cr}(\mathrm{III})$ oxidation. Therefore, the formation of an complex between $\mathrm{Cr}$ (III) and $\mathrm{Mn}(\mathrm{IV})$ could easily be the rate limit since both $\mathrm{Mn}(\mathrm{IV})$ and $\mathrm{Cr}$ (III) have high ligand field stabilization energies and slow ligand field stabilization (Klewicki and Morgan 1998).

\section{Conclusions}

The present study focused on the $\mathrm{Cr}$ (III) oxidation capacities of biogenic and chemically synthetic $\mathrm{Mn}$ oxides and the possible $\mathrm{Cr}(\mathrm{III})$ oxidation mechanism in the presence of Mn-oxidizing bacterium Bacillus sp. WH4. Results showed that the Cr(III) oxidation capacity of biogenic $\mathrm{Mn}$ oxide was higher than synthetic $\mathrm{Mn}$ oxides. Bacillus sp. WH4 promoted Cr(III) oxidation through biogenic Mn oxide formation. In a system with Bacillus sp. WH4, an oxidation cycle was created. Although Mn(II) was needed, higher Mn(II) concentration would inhibit $\mathrm{Cr}(\mathrm{III})$ oxidation through physical blocking or site competition.

The binding of $\mathrm{Cr}$ to Mn oxides could greatly affect their phase distributions and fate in many natural systems. The participation of Mn-oxidizing bacteria makes this system more complicated. A better understanding of $\mathrm{Cr}(\mathrm{III})$ oxidation in the presence of Mn-oxidizing bacteria in the natural aqueous system is essential to consider the fates and transports of not only $\mathrm{Cr}$ but also many other heavy metals. It is also important when considering the potential application of $\mathrm{Mn}$ oxides in the remediation of environmental pollutants because $\mathrm{Mn}$ oxides may lead unexpected risks. Further research is needed to analyze the $\mathrm{Cr}$ speciation in natural system and fully understand $\mathrm{Cr}(\mathrm{III})$ oxidation coupled with $\mathrm{Mn}(\mathrm{II})$ bacterial oxidization.

Acknowledgments This work was supported by the Ministry of Science and Technology of China (2005CB121104), the Chinese Academy of Sciences (KZCX1-YW-06-03), and the Natural Science Foundation of China (40671172).

\section{References}

Bargar JR, Tebo BM, Bergmann U, Webb SM, Glatzel P, Chiu VQ, Villalobos M (2005) Biotic and abiotic products of $\mathrm{Mn}(\mathrm{II})$ oxidation by spores of the marine Bacillus sp. strain SG-1. Am Miner 90:143-154

Bartlett RJ, James BR (1988) Chromium in the natural and human environments. Wiley, New York

Chinni S, Anderson CR, Ulrich KU, Giammar DE, Tebo BM (2008) Indirect $\mathrm{UO}_{2}$ oxidation by $\mathrm{Mn}(\mathrm{II})$-oxidizing spores of Bacillus sp. 
strain SG-1 and the effect of $\mathrm{U}$ and Mn concentrations. Environ Sci Technol 42:8709-8714

Chung JB, Zasoski RJ, Lim SU (1994) Kinetics of chromiumu(III) oxidation by various manganese oxides. Agr Chem Biotechnol 37:414-420

Fendorf SE, Zasoski RJ (1992) Chromium(III) oxidation by $\delta-\mathrm{MnO}_{2} .1$. Characterization. Environ Sci Technol 26:79-85

Feng XH, Liu F, Tan WF, Liu XW (2004a) Synthesis of birnessite from the oxidation of $\mathrm{Mn}^{2+}$ by $\mathrm{O}_{2}$ in alkali medium: Effects of synthesis conditions. Clay Clay Miner 52:240-250

Feng XH, Tan WF, Liu F, Wang JB, Ruan HD (2004b) Synthesis of todorokite at atmospheric pressure. Chem Mater 16:4330-4336

Feng XH, Zhai LM, Tan WF, Liu F, He JZ (2007) Adsorption and redox reactions of heavy metals on synthesized $\mathrm{Mn}$ oxide minerals. Environ Pollut 147:366-373

Hastings D, Emerson S (1986) Oxidation of manganese by spores of a marine bacillus: Kinetic and thermodynamic considerations. Geochim Cosmochim Ac 50:1819-1824

He JZ, Zhang LM, Jin SS, Zhu YG, Liu F (2008) Bacterial communities inside and surrounding soil iron-manganese nodules. Geomicrobiol J 25:14-24

Jin SS, He JZ, Zheng YM, Meng YT, Zhang LM (2009) Adsorption of heavy metals by biogenic manganese oxides. Acta Scientiae Circumstantiae 29:132-139

Kim HS, Pasten PA, Gaillard JF, Stair PC (2003) Nanocrystalline todorokite-like manganese oxide produced by bacterial catalysis. J Am Chem Soc 125:14284-14285

Klewicki JK, Morgan JJ (1998) Kinetic behavior of Mn(III) complexes of pyrophosphate, EDTA, and citrate. Environ Sci Technol 32:2916-2922

Krumbein WE, Altmann HJ (1973) A new method for the detection and enumeration of manganese oxidizing and reducing microorganisms. Helgoland Mar Res 25:347-356

Lee YT, Tebo BM (1994) Cobalt(II) oxidation by the marine manganese(II)-oxidizing Bacillus sp. strain SG-1. Appl Environ Microbiol 60:2949-2957

Meng YT, Zheng YM, Zhang LM, He JZ (2009) Biogenic Mn oxides for effective adsorption of $\mathrm{Cd}$ from aquatic environment. Environ Pollut 157:2577-2583

Morgan JJ (2005) Kinetics of reaction between $\mathrm{O}_{2}$ and $\mathrm{Mn}$ (II) species in aqueous solutions. Geochim Cosmochim Ac 69:35-48

Murray KJ, Tebo BM (2007) Cr(III) is indirectly oxidized by the Mn (II)-oxidizing bacterium Bacillus sp. strain SG-1. Environ Sci Technol 41:528-533

Murray KJ, Mozafarzadeh ML, Tebo BM (2005) Cr(III) oxidation and $\mathrm{Cr}$ toxicity in cultures of the manganese(II)-oxidizing Pseudomonas putida strain GB-1. Geomicrobiol J 22:151-159

Murray KJ, Webb SM, Bargar JR, Tebo BM (2007) Indirect oxidation of $\mathrm{Co}(\mathrm{II})$ in the presence of the marine $\mathrm{Mn}$ (II)-oxidizing bacterium Bacillus sp. strain SG-1. Appl Environ Microbiol 73:6905-6909

Nealson KH, Tebo BM, Rosson RA, Allen IL (1988) Occurrence and mechanisms of microbial oxidation of manganese. Adv Appl Microbiol 33:279-318
Nelson YM, Lion LW, Ghiorse WC, Shuler ML (1999) Production of biogenic Mn oxides by Leptothrix discophora SS-1 in a chemically defined growth medium and evaluation of their $\mathrm{Pb}$ adsorption characteristics. Appl Environ Microbiol 65:175-180

Nico PS, Zasoski RJ (2000) Importance of Mn(III) availability on the rate of $\mathrm{Cr}(\mathrm{III})$ oxidation on $\delta-\mathrm{MnO}_{2}$. Environ Sci Technol 34:3363-3367

Ohnuki T, Ozaki T, Kozai N, Nankawa T, Sakamoto F, Sakai T, Suzuki Y, Francis AJ (2008) Concurrent transformation of Ce(III) and formation of biogenic manganese oxides. Chem Geol 253:23-29

Oze C, Bird DK, Fendorf S (2007) Genesis of hexavalent chromium from natural sources in soil and groundwater. PNAS 104:6544 6549

Rophael MW (1982) Kinetics of the oxidation of chromium (III) by manganese (III) in sulfuric-acid medium. Chemica Scripta 20:171-173

Rosson RA, Nealson KH (1982) Manganese binding and oxidation by spores of a marine Bacillus. J Bacteriol 151:1027-1034

Silvester E, Charlet L, Manceau A (1995) Mechanism of chromium (III) oxidation by Na-buserite. J Phys Chem 99:16662-16669

Tebo BM, Bargar JR, Clement BG, Dick GJ, Murray KJ, Parker D, Verity R, Webb SM (2004) Biogenic manganese oxides: Properties and mechanisms of formation. Annu Rev Earth Pl Sci 32:287-328

Toner B, Manceau A, Webb SM, Sposito G (2006) Zinc sorption to biogenic hexagonal-birnessite particles within a hydrated bacterial biofilm. Geochim Cosmochim Ac 70:27-43

Urone PF (1955) Stability of colorimetric reagent for chromium, sdiphenylcarbazide, in various solvents. Anal Chem 27:1354 1355

Villalobos M, Toner B, Bargar J, Sposito G (2003) Characterization of the manganese oxide produced by Pseudomonas putida strain MnB1. Geochim Cosmochim Ac 67:2649-2662

Villalobos M, Bargar J, Sposito G (2005) Mechanisms of Pb(II) sorption on a biogenic manganese oxide. Environ Sci Technol 39:569-576

Weaver RM, Hochella JMF (2003) The reactivity of seven Mn-oxides with $\mathrm{Cr}^{3+\text { aq. }}$ A comparative analysis of a complex, environmentally important redox reaction. Am Miner 88:2016-2027

Weaver RM, Hochella JMF, Ilton ES (2002) Dynamic processes occurring at the $\mathrm{Cr}^{\text {IIIaq }}$-manganite $(\gamma-\mathrm{MnOOH})$ interface: simultaneous adsorption, microprecipitation, oxidation/reduction, and dissolution. Geochim Cosmochim Ac 66:4119-4132

Webb SM, Dick GJ, Bargar JR, Tebo BM (2005) Evidence for the presence of $\mathrm{Mn}(\mathrm{III})$ intermediates in the bacterial oxidation of Mn(II). PNAS 102:5558-5563

Wu Y, Deng BL, Xu H, Kornishi H (2005) Chromium(III) oxidation coupled with microbially mediated $\mathrm{Mn}(\mathrm{II})$ oxidation. Geomicrobiol J 22:161-170

Zhang LM, Liu F, Tan WF, Feng XH, Zhu YG, He JZ (2008) Microbial DNA extraction and analyses of soil iron-manganese nodules. Soil Biol Biochem 40:1364-1369 